\title{
KEBIJAKAN PEMERINTAH DAERAH KOTA DALAM MENANGANI POLUSI UDARA DI WILAYAH PERKOTAAN
}

\author{
Henita Rahmayanti
}

\begin{abstract}
Abstrak
Tujuan Penulisan ini memberikan gambaran mengenai transportasi di daerah perkotaan khususnya kota-kota yang telah di kategorikan sebagai kota metropolitan dan penanganan polusi udara yang ditimbulkan oleh kemacetan, serta beberapa tujuan lain, yaitu: mengetahui bagaimana kebijaksanaan pemerintah dalam menangani masalah kemacetan, mengetahui bagaimana kebijaksanaan pemerintah dalam mengatasi/mereduksi polusi udara yang ditimbulkan oleh kemacetan, mengetahui zatzat berbahaya yang terkandung dalam polutan.
\end{abstract}

Kata Kunci : Transportasi, perkotaan, kebijakan, kualitas udara

\section{PENDAHULUAN}

Transportasi di perkotaan saat ini sudah dipastikan menimbulkan dampak diberbagai aspek kehidupan, dan yang paling menonjol adalah bidang ekonomi dan kesehatan. Hal tersebut sering kita lihat di setiap harinya, kemacetan yang terjadi dapat menimbulkan kerugian besar di bidang ekonomi hanya dalam hitungan waktu (jam, menit, bahkan detik), pemborosan bahan bakar, penurunan komponen kendaraan, penurunan nilai barang yang akan dikirim, semua ini secara ekonomis merupakan penyebab kerugian dalam hal kegiatan operasional suatu perusahaan dalam menjalankan bisnisnya. Dari kerugian yang di timbulkan oleh kemacetan tersebut dapat menimbulkan kenaikan harga barang yang disebabkan keterlambatan waktu pengiriman barang ketempat tujuan

Dampak buruk yang di timbulkan kemacetan dalam bidang kesehatan lebih besar dibanding dalam bidang ekonomi, udara di perkotaan sudah tercemar dan terkontaminasi oleh asap kendaraan bermotor yang lalu lalang disetiap jalan di sepanjang harinya. Polusi yang di timbulkan menyebabkan berbagai dampak negatif bagi lingkungan terutama bagi kesehatan manusia. Udara perkotaan yang terakumulasi olah zat karbon dari kendaraan

Henita Rahmayanti, Dra, MSi

Staf Pengajar Jurusan Teknik Sipil

Fakultas Teknik

Universitas Negeri Jakarta, 13220 
menimbulkan dampak pemanasan global (global warming) yang menjadikan suhu udara meningkat lebih panas. Kesehatan manusia juga tak luput dari dampak buruk yang di timbulkan polusi udara, kanker kulit, penyakit paru-paru, kanker otak pada anak kecil, dan banyak dampak lain.

Penulisan ini memberikan gambaran mengenai transportasi di daerah perkotaan khususnya kota-kota yang telah di kategorikan sebagai kota metropolitan dan penanganan polusi udara yang ditimbulkan oleh kemacetan, serta beberapa tujuan lain, yaitu :

- Mengetahui bagaimana kebijaksanaan pemerintah dalam menangani masalah kemacetan.

- Mengetahui bagaimana kebijaksanaan pemerintah dalam mengatasi polusi udara yang menimbulkan oleh kemacetan.

- Mengetahui zat-zat berbahaya yang terkandung dalam polutan.

\section{PEMBAHASAN}

\section{Sistem Pergerakan Transportasi}

Dalam pemecahaan permasalahan transportasi dibutuhkan arah kebijakan yang jelas untuk pemenuhan kebutuhan transportasi dengan tujuan mengoptimalkan pemanfaatan prasarana yang sudah ada, pengembangan transportasi berbasiskan massal, mengendalikan kebutuhan transportasi serta meningkatkan keselamatan lalu lintas dan berwawasan lingkungan.

Sistem pergerakan yang terjadi diakibatkan oleh sistem kegiatan dan sistem jaringan serta dipengaruhi oleh sistem kelembagaan yang ada. Sistem-sistem ini di uraikan sebagai berikut :

a. Sistem kegiatan, diwujudkan oleh ruang kegiatan masyarakat, wilayah perkotaan merupakan pusat kegiatan yang diwarnai oleh tingginya kepadatan, ragam serta dinamika dari penduduk, dan juga tingginya tingkat kegiatan perdagangan industri.

b. Sistem jaringan, terdiri dari jaringan transportasi jalan yang meliputi jaringan jalan, jaringan trayek pelayanan angkutan umum, jaringan lintas angkutan barang dan simpul/terminal. 
c. Sistem pergerakan, merupakan wujud dari kebutuhan transportasi yang didistribusikan melalui jaringan jalan dengan menggunakan moda angkutan tertentu.

d. Sistem kelembagaan, yang berfungsi untuk mengoptimalkan ketiga sistem diatas dalam wujud :

○ Peraturan perundangan.

- Perencanaan dan perwujudan rencana sistem transportasi

$\circ \quad$ Keuangan dan pendanaan

○ Pengendalian sistem

\section{Arah Dan Kebijaksanaan Pembangunan Sektor Transportasi}

Untuk menjamin pertumbuhan ekonomi dan mengatasi kebutuhan angkutan di daerah perkotaan di butuhkan fasilitas yang saling menghubungkan antara wilayah kota, pemukiman, daerah komersil dan rekreasi. Sasaran umum kebijaksanaan pemerintah di dalam lalu lintas dan angkutan kota adalah untuk menciptakan.suatu sistem transportasi di wilayah perkotaan sehingga mobilitas orang dan barang dapat menunjang pertumbuhan ekonomi dan memenuhi perniagaan serta aktifitas sosial masyarakat. Sesuai dengan yang digariskan oleh pemerintah pokok-pokok kebijaksanaan sistem transportasi di wilayah perkotaan adalah :

a. Pembangunan transportasi diarahkan pada terwujudnya sistem transportasi nasional yang andal, berkemampuan tinggi dan diselenggarakan secara terpadu.

b. Meningkatkan kebijakan yang berkaitan dengan peningkatan kemampuan Sumber Daya Manusia sehingga terwujud, baik keandalan pelayanan maupun keterpaduan antar dan intra moda transportasi yang disesuaikan dengan perkembangna ekonomi, teknologi, tata ruang lingkungan hidup, kebijaksanaan energi nasional dan tuntutan masyarakat dan kebutuhan perdagangan baik nasional dan internasional dengan memperhatikan maupun kelaikan sarana tansportasi.

c. Peran serta pihak swasta dan koperasi dalam penyelenggaraan transportasi perlu didorong dan digalakkan melalui penciptaan iklim yang menumbuhkan kompetisi yang sehat dan saling menghidupi, sesuai dengan peraturan perundanganundangan yang berlaku dan mengabdi pada kepentingan nasional. 
d. Di wilayah perkotaan dikembangkan transportasi massal yang tertib, lancar dan aman dan nyaman dan efesien agar menimbulkan daya tarik bagi pemakai jasa transportasi serta dapat menghindari kemacetan dan gangguan lalu lintas dan memberikan kualitas lingkungan hidup dapat dipertahankan.

e. Pembangunan transportasi darat diarahkan pada pengembangan secara terpadu anatara transportasi jalan raya, kereta api, sungai, danau dan penyebrangan melalui pembangunan sarana, prasarana dengan meningkatkan manajemen dan pelayanan serta pembinaan pemakai jalan dan kejelasan informasi agar dapat memacu pembangunan di semua sektor.

f. Pembangunan jalan raya perlu ditumbuh kembangkan dan diserasikan dengan perkembangan transportasi jalan raya antara beban dan kepadatan lalu lintas kendaraan dengan kemampuan daya dukung jalan, jaringan jalan di pusat pertumbuhan, pusat produksi dan menghubungkan antara pusat produksi dengan daerah pemasaran. Pembangunan jalan tol bebas hambatan tatap memperhatikan adanya jalan alternatif yang memadai.

g. Dalam rangka meningkatkan pelayanan angkutan dalam kota dan antar kota diusahakan pengembangan sistem angkutan kereta api (massal).

\section{Arah Dan Kebijakasanaan Sektor Pembangunan Daerah}

Untuk meyelaraskan kebijaksanaan transportasi dengan kebijaksanaan pembangunan daerah, berikut dikemukakan kebijaksanaan pembangunan daerah utamanya yang berkaitan dengan kebijaksanaan pembangunan wilayah perkotaan sebagai berikut:

a. Peran serta masyarakat dalam pembangunan perlu lebih dikembangkan melalui pelimpahan wewenang dan tanggung jawab, khususnya daerah perkotaan.

b. Kerjasamaa antara daerah dalam rangka pembangunan daerah dan pengembangan wilayah didorong dan ditingkatkan agar berbagai daerah dapat tumbuh secara serasi dan mampu memecahkan masalah yang terdapat di wilayah dan 
daerah secara bersama. Kemampuan daerah untuk melakukan pembangunan yang berwawasan lingkungan ditingkatkan melalui pendayagunaan sumber daya alam dan pembinaan sumber daya manusia yang terdapat didaerah yang bersangkutan secara berencan, terpadu dan dengan memperhatikan saling ketergantungan dengan daerah lain dan dalam rangka nasional.

c. Dalam pelaksanaan pembangunan daerah prakarsa dan peran aktif masyarakat beserta lembaga perencanaan daerah ditingkatkan, pengamanan dan koordinasi pembangunan makin dimantapkan, serta fungsi lembaga perwakilan daerah lebih didayagunakan sebagai perwujudan peran serta masyarakat dalam pembangunan. Kemampuan manajemen pembangunan seluruh aparatur pemerintah daerah ditingkatkan, untuk lebih mendayagunakan potensi daerah dan makin mewujudkan otonomi daerah yang nyata, dinamis serasi dan bertanggung jawab.

d. Pebangunan perkotaan ditingkatkan dan diselenggarakan secara berencana dan terpadu dengan memperhatikan rencana umum tata ruang, pertumbuhan penduduk,lingkungan pemukiman, lingkungan usaha dan lingkungan kerjaserta kegiatan ekonomi dan kegiatan sosial lainnya agar terwujud pengelola perkotaan yang sehat, rapi, aman dan nyaman. Perhatian khusus perlu diberikan pada peningkatan sarana dan prasarana umum yang layak. Keserasian hubungan antara masyarakat perkotaan dan pedesaan serta antara masyarakat terus di upayakan agar terwujud keserasian kehidupan masyarakat dalam segala aspek kehidupan.

\section{Rumus Kebijaksanaan dan Strategi Transportasi Wilayah Perkotaan}

Arahan kebijaksanaan pemerintah sebagaimana terdapat dalam ketetapan MPR No. II/MPR/1998, pembangunan transportasi diarahkan pada pemantapan sistem transportasi nasional (SISTRANAS) yang maju dan andal sesuai dengan peranannya sebagai urat nadi kehidupan ekonomi, sosial budaya, politik dan pertahanan keamanan serta untuk memperkukuh persatuan dan kesatuan bangsa. Selanjutnya juga dinyatakan bahwa penetapan sistem angkutan massal dikembangkan untuk daerah perkotaan. Berdasarkan arahan-arahan yang diberikan tersebut, tujuan perencanaan transportasi di wilayah perkotaan dalam jangka dirumuskan sebagai berikut: 
"penataan dan pengembangan angkutan umum perkotaan yang terjangkau denga memperhatikan tata ruang, fungsi dan mutu lingkungan hidup, sehingga wilayah perkotaan dan sekitarnya makin berfungsi baiksebgai kawasan pemukiman mau-pun pusat-pusat produksi, jasa, perdagangan, sedang di wilayah kota raya dan kota besar perlu dikembangkan transportasi missal cepat yang tertib aman, lancer, nyaman dan efisien serta terjangkau agar tercipta sistem transportasi perkotaan yang seimbang dan terpadu"

Untuk mencapai tujuan tersebut, pemerintah telah membentuk suatu kebijaksanaan yang selanjutnya akan diaplikasikan atas kebijaksanaan-kebijaksanaan Jangka Panjang, Jangka Menengah, dan Jangka Pendek.

\section{Tujuan}

Tujuan yang tercangkup dalam kebijaksanaan jangka panjang akan dicapai melalui strategi pengembangan angkutan perkotaan terutama dipusatkan pada hal-hal berikut :

- Pengembangan sistem transportasi penumpang dan barang

- Pengembangan sistem angkutan jalan rel di daerah perkotaan

- Peningkatan pengelolaan dan kualitas pelayanan sistem angkutan massal perkotaan

- Meningkatkan kemampuan pengendalian dan peraturan lalu lintas

Dalam rangka tujuan-tujuan dan strategi-strategi yang ditetapkan tersebut, telah diidentifikasikan 9 (sembilan) kebijaksanaan.

\section{1) Kerangka hukum dan pengaturan}

Melaksanakan kerangka hukum peraturan yang modern serta dalam pengembangan sistem angkutan perkotaan.

\section{2) Pengembangan institusi dan koordinasi}

Meningkatkan kemampuan dan efisiensi diantara badan-badan yang terkait dalam pengembangan, pengaturan dan pengoperasian sistem angkutan perkotaan dikaitkan dengan karakteristik, sosial-ekonomi dan demografi dari masing-masing wilayah perkotaan 
3) Pengintegrasian Perencanaan Dan Kebijaksanaan Sektor Angkutan Perkotaan Meningkatkan integrasi dalam pembentukan perencanaan dari kebijaksanaan sektor transportasi perkotaan, terutama yang berkaitan dengan pengembangan system.

Transportasi perkotaan yang diterintegrasi antara berbagai moda transportasi dalam kaitannya dengan peran dan kekuatan masing-masing individu dalam melayani pergerakan perkotaan.

4) Pembangunan Infrastuktur Angkutan Jalan Perkotaan mengatur pengembangan infrastruktur jalan perkotaan secara berjenjang (hierarki jalan) dalam rangka memadukan perpindahan fasilitas perpindahan intra moda yang efisien dan efektik.

5) Meningkatkan Pengaturan Lalu Lintas Di Daerah-Daerah Perkotaan

Mengembangkan dan melaksanakan langkah-langkah perbaikan lalu lintas yang bertujuan untuk meningkatkan efisien dan kualitas pelayanan dari infrastruktur jalan yang ada dengan penekanan utama pada pelaksanaan langkah-langkah kebijaksanaan jangka pendek yang bersifat "low-cost" dan mudah untuk melaksanakan.

6) Meningkatkan Pelayanan Angkutan Umum Perkotaan

Peningkatan kualitas pelayanan sistem angkutan umum bus melalui pengelolaan dan pengoperasian yang lebih baik dari perusahaan-perusahaan bus, dan meningkatkan partisipasi peran swasta dalam pengadaan pelayanan angkutan bis di wilayah perkotaan.

\section{7) Pengembangan Sistem Angkutan Cepat Massal}

Mengintrodusir system angkutan cepat missal pada koridor-koridor dengan tingkat permintaan penumpang yang tinggi dengan mempertimbangkan aspek-aspek sosial, ekonomi, teknologi dan kemungkinan-kemungkinan pelaksanaannya.

8) Meningkatkan Keselamatan Lalu Lintas Di Jalan

Meningkatkan keselamatan lalu lintas di jalan untuk daerah perkotaan melalui pengoprerasian dan penga-turan system lalu lintas yang lebih untuk mengurangi jumalh kecelakaan, serta penerapan prinsip-prinsip keselamatan lalu lintas dalam peren-canaan, penyusunan dan pendanaan untuk mencegah terjadinya kecela-kaan pada daerah-daerah berpotensi kecelakaan. 


\section{9) Pengendalian Lingkungan Perkotaan}

Memperbaiki kualitas lingkungan dengan cara yang komprehensip dalam rangka masalah polusi udara yang disebabkan oleh emisi kendaraan dan kebisingan dan getaran dengan juga melakukan peningkatan teknologi dalam bidang permesinan, kontrol tata-guna lahan (land use) sekaligus membentuk perncanaan jalan yang lebih baik, memberikan struktur kekuatan perkerasan, dan sedapat mengkin menghindari terjdinya ganguan pandangan (visual intrusions)

Kebijaksanaan nasional ini di pergunakan sebagai arahan dalam pengembangan system angkutan umum diseluruh Indonesia, disamping sebagai kerangka dasar dalam mengembangkan rencana pengembangan angkutan perkotaan.

\section{Dasar Rumusan Kebijakan}

Dasar perumusan kebijakan pembangunan sektor transportasi wilayah perkotaan ditujukan untuk " meningkatkan penyediaan jasa transportasi yang terpadu, tertib, lancar, aman, nyaman dan efisien, serta mendukung, mendorong dan mewujudkan :

$>$ Kebijaksanaan tata ruang

$>$ Pelimpahan wewenang dan tanggung jawab kepada daerah, khususnya daerah otonom

> Kerjasama antara daerah, untuk mendorong keserasian pertumbuhan wilayah perkotaan dan daerah berikutnya.

$>$ Peningkatan mobilitas yang terbaru kemampuan manajemen oprator pemerintah, terutama daerah.

> Pertumbuhan penduduk lingkungan pemukiman, lingkungan usaha, lingkungan kerja, serta kegitan ekonomi dan sosial.

> Prioritas kepada peningkatan sarana dan prasarana angkutan umum.

> Pengembangan angkutan umum massal yang ekonomis dan aman.

> Keterpaduan antar dan intra moda

> Pembangunan jalan tol bebas hambatan yang mendukung sistem transportasi cepat

$>$ Pola distribusi nasional 
Pembangunan jalan transportasi yang strategis

$>$ Kelaikan sarana transportasi perkotaan

> Mempersembahkan kualitas lingkungan hidup.

\section{Kualitas Udara Perkotaan Makin Memprihatinkan}

Evaluasi kualitas udara perkotaan Indonesia dalam konteks transportasi berkelanjutan, Deputi II MENLH menyatakan bahwa konferensi pers ini merupakan kick off dan kegiatan evaluasi kulitas udara perkotaan di Indonesia. Hal ini dilaksanakan sebagai respon pemerintah terhadap berbagai permasalahan pencemaran udara di berbagai wilayah terutama di kota besar.

Dari data tahun 2006 yang diperoleh KLH melalui uji petik / spot-check di enam kota besar yaitu Yogyakarta, Denpasar, Surabaya, Balik Papan, Makassar dan Jakarta, ditemukan untuk kendaraan berbahan bakar bensin, kurang lebih 50\% tidak memenuhi ambang batas, sementara untuk kendaraan berbahan bakar solar hampir $90 \%$ tidak memenuhi ambang batas.

Untuk itu diperlukan adanya perubahan paradigma dalam mengembangkan sistem transportasi ke depan. "Salah satu konsep yang saat ini mengemukakan adalah konsep transportasi berkelanjutan (sustainable transportation) dimana konsep ini berupaya mewujudkan suatu sistem transportasi yang menggunakan sumber daya ekonomi secara efisien, dan dapat dinikmati oleh seluruh strata sosial secara adil. Salah satu alat yang dapat digunakan adalah melalui kriteria transportasi berkelanjutan yang sudah disusul oleh KLH" demikian menteri Negara lingkungan hidup, Ir. Rachmat Witoelar menyatakan.

Dalam aplikasi kriteria ini adalah salah satunya akan mengukur kualitas udara secara fisik yaitu:

1. Pemantauan kualitas udara ambient, roadside (jalan raya)

2. Uji emisi kendaraan

3. Traffic Counting (kerapatan dan kecepatan)

4. Pengisian data non teknis

Untuk tahub ini KLH akan mengevaluasi 10 kota metropolitan dan satu kota besar melalui evaluasi ini berharap kualitas udara di perkotaan menjadi prioritas program masing-masing kota sehingga di hasilkan kondisi kualitas udara yang lebih baik 
Hampir tidak ada kota di dunia ini yang dapat menghidari dari bencana modern pencemaran udara. Bahkan kota-kota dahulu yang terkenal dengan udaranya yang murni, tak tercemar, sekarang selalu dikepung oleh udara tercemar sehingga dapat menumbuh dan dapat membuat orang baik yang sehat maupun yang tidak sehat masuk rumah sakit. Tapi hal itu tak perlu terjadi, karena kota-kota dan bangsa-bangsa di seluruh duni mulai menerapkan berbagai strategi yang dapat mengatasi masalah pencemaran udara dengan baik. Strategi itu mulai dari larangan parkir dan hari tanpa mengemudi sampai program ketat dan berkekuatan hokum untuk memasang kendali pencemaran yang canggih di pusat-pusat pembangkit tenaga.hanya sedikit usaha ini yang mencapai keberhasilan sempurna, tetapi banyak juga yang cukup berhasil bahkan begitu berhasilnya terkadang mendapat perhatian.

\section{Sumber Pencemaran Udara}

Organisati kesehatan dunia (WHO) memperkirakan bahwa $70 \%$ penduduk kota di dunia pernah sesekali menghirup udara yang tidak sehat, sedangkan $10 \%$ lain menghirup udara yang bersifat "marjinal". Studi oleh para peneliti di Universitas Harvard menunjukan bahwa kematian akibat pencemaran udara berjumlah antara 50.000 dan 100.000 pertahun.

Pencemaran lebih mempengaruhi anak-anak miskin yang terjangkit pada banyak jenis polutan dan tingkat pencemaran yang lebih tinggi di kota dengan tingkat pencemaran udara lebih tinggi mempunyai paru-paru lebih kecil, sering tidak bersekolah karena sakit. Rendahnya berat badan anak-anak dan kecilnya organ-organ pertumbuhan mereka memberi resiko yang lebih tinggi pula bagi mereka. Demikian pula kebiasaan mereka : bayi menghisap sembarang benda-benda yang tercemar, anak-anak yang lebih besar bermainmain di jalanana yang di penuhi asap kendaraan dan buangan hasil pembakaran bermuatan timah. Di daerah-daerah yang jauh dari fasilitas industri, pencemaran udara juga dapat menyebabkan kerusakan, para ilmuan melaporkan adanya tingkat hujan asam dank abut asap kemungkinan karena pembakran rutin untuk melapangkan tanah. 


\section{Bahan Pencemar Udara Khusus.}

\section{Karbon monoksida}

WHO telah membuktikan bahwa karbon monoksida yang secara rutin mencapai tingkat tak sehat di banyak kota dapat mengakibatkan kecilnya berat badan janin, meningkatkan kematian bayi dan kerusakan otak, bergantung pada lamanya seorang wanita hamil terpanjang, dan bergantung pada kekentalan polutan di udara.

Asap kendaraan merupakan sumber hamper seluruh karbon monoksida yang dikeluarkan di banyak daerah perkotaan. Karena itu strategi penurunan kadar karbon monoksida yang berhasil bergantung terutama pada pengendalian emisi otomatis seperti pengubah kalitis, yang mengubah sebagian besar karbon menjadi karbon dioksida.

\section{Nitrogen Oksida}

Nitrogen oksida yang terjadi ketika panas pembakaran menyebabkan bersatunya oksigen dan nitrogen yang terdapat di udara memberikan berbagai ancaman berbahaya. Zat nitrogen ini sendiri menyebabkan kerusakan paru-paru. Setelah beraksi di atmosfer, zat ini membentuk partikel-partikel nitrat ini pula, jika bergabung dengan air, baik air di paru-paru atau uap air di awan akan membentuk asam. Akhirnya zat-zat oksida ini bereaksi dengan asap bensin yang tidak terbakar dan zat-zat hidrokarbon lain di sinar matahari dan membentuk ozon rendah atau "smog" kabut berwarna kemerahan yang menyelimuti sebagian besar kota di dunia.

\section{Sulfur Dioksida}

Emisi sulfur dioksida terutama timbul dari pembakaran bahan fosil yang mengandung sulfur terutama batu bara yang digunakan untuk pembangkit tengaga listrik atau pemanasan rumah tangga. System pemantauan lingkungan global yang di sponsori PBB memperkirakan bahwa pada 1987 dua pertiga penduduk kota hidup di kota-kota yang konsentrasi sulfur dioksida di udara sekitarnya di atas atau tepat pada ambang batas yang ditetapkan WHO.gas yang berbau tajam tapi tak berwarna ini dapat menimbulkan serangan asma dan karena gas menetap di udara, bereaksi dan membentuk partikelpartikel halus dan zat asam. 


\section{Benda Partikulat}

Zat ini sering disebut asap atau jelaga ; benda-benda partikulat ini sering merupakan pencemar udara yang paling ketara, dan biasanya juga paling berbahya. Sistem pemantauan lingkungan global yang disponsori PBB memperkirakan pada 1987 bahwa 70 persen penduduk kota di dunia hidup di kota-kota dengan partikel yang mengambang di udara melebihi ambang batas yang ditetapkan WHO.

Sebagian benda partikulat keluar dari cerobong pabrik sebagai asap hitam tebal, tetapi yang paling berbahaya adalah "partikel-partikel halus"butiran-butiran yang begitu kecil sehingga dapat menembus bagian yang terdalam paru-paru. Sebagian beasr partikel halus ini berbentuk dengan polutan lain, terutama sulfur dioksida dan oksida nitrogen, dan secara kimiawi berubah dan membentuk zat-zat nitrat dan sulfat. Di beberapa kota, sampai separuhjumlah benda partikulat yang disebabkan ulah manusia terbentuk dari perubahan sulfur dioksida menjadi partikel sulfat di atmosfer. Di kota-kota lain nitrat yang terbentuk dari proses yang sama dari oksida-oksida nitrogen dapat membentuk sepertiga atau lebih benda partikulat.

\section{Hidro karbon}

Zat ini kadang-kadang disebut senyawa organic yang mudah menguap ("volatile organic compounds NOC"). Dan juga sebagaigas organic reaktif (reactive organic gases/ROG"), hidrokarbon merupakan uap bensin yang tidak tebakar dan produk samping dari pembakaran tak sempurna. Jenis-jenis hidrokarbon lain, yang sebagian menyebabkan leukemia,kanker, atau penyakit-penyakit serius lain berbentuk cairan untuk cuci-kering pakaian sampai zat penghilang lemak untuk industri.

\section{Laju Pelaksanaan Untuk Kendaraan Beremisi Nol atau Mendekati Nol (TLEV, LEV, ULEV dan ZEV)}

Bagan di bawah menunjukan laju yang harus diterapkan pabrik mobil dalam memulai penjualan kendaraan baru yang kurang berpolusi sebagaimana diisyaratkan dengan menggunakan emisi hidrokarbon sebagai contoh. Misalnya, pada 1998; $48 \%$ penjualan mobil baru harus memenuhi suatu batas emisi sebesar 0,25 gram perkilometer; $48 \%$ lagi harus memenuhi standar kendaraan beremisi rendah (LEV) setinggi 0,075 gram 
perkilometer; 2 harus memenuhi standar kendaraan beremisi ultra rendah (ULEV) setinggi 0,040; dan $2 \%$ lagi harus berupa kendaraan beremisi nol (ZEV). Rata-rata bagi semua mobil adalah 0,115 gram perkilometer.

\begin{tabular}{|c|c|c|c|c|c|c|c|}
\hline \multirow{2}{*}{ Model } & & TLEV & LEV & ULEV & ZEV & \multicolumn{2}{|c|}{ Standar } \\
\hline & & & & & & & \\
\hline & 0.39 & 0.25 & 0.125 & 0.075 & 0.040 & 0.00 & Rata-rata \\
\hline Tahun & & & & & & & Mobil \\
\hline 1994 & $10 \%$ & $80 \%$ & $10 \%$ & & & & 0.250 \\
\hline 1995 & & $85 \%$ & $15 \%$ & & & & 0.231 \\
\hline 1996 & & $89 \%$ & $20 \%$ & & & & 0.225 \\
\hline 1997 & & $73 \%$ & & $2 \%$ & $25 \%$ & & 0.202 \\
\hline 1998 & & $48 \%$ & & $2 \%$ & $48 \%$ & $2 \%$ & 0.157 \\
\hline 1999 & & $23 \%$ & & $2 \%$ & $73 \%$ & $2 \%$ & 0.113 \\
\hline 2000 & & & & $2 \%$ & $96 \%$ & $2 \%$ & 0.073 \\
\hline 2001 & & & & $5 \%$ & $90 \%$ & $5 \%$ & 0.070 \\
\hline 2002 & & & & $10 \%$ & $85 \%$ & $5 \%$ & 0.068 \\
\hline 2003 & & & & $15 \%$ & $75 \%$ & $10 \%$ & 0.062 \\
\hline
\end{tabular}

\section{Ozon atau Kabut Fotokimiawi}

Ozon, terdiri dari beratus-ratus zat kimiawi yang terdapat dalam asap kabut, terbentuk ketika hidrokarbon pekat di perkotaan bereaksi dengan oksida nitrogen. Tetapi karena salah satu zat kimiawi itu, yaitu ozon adalah yang paling dominan, pemerintah menggunakannya sebagai tolak ukur untuk menetapkan kosentrasi oksidan secara umum.Ozon merupakan zat oksidan yang begitu kuat (selain klor) sehingga beberapa kota menggunakannya sebagai disinfektan pasokan air minum. Banyak ilmuan menganggapnya sebagai polutan udara yang paling beracun ; begitu membahayakannya sehingga pada eksperimen laboraturium untuk menguji dampak ozon, satu dari setiap sepuluh sukarelawan harus dipindahkan dari bilik pajanan yang digunakan dalam eksperimen itu karena gangguan pernapasan. Pada hewan percobaan laboratorium, ozon menyebabkan luka dan kerusakan sel yang mirip dengan yang diderita para perokok. 
Karena emisi oksida nitrogen dan hidrokarbon semakin meningkat, tingkat ozon bahkan di pedesaan telah berlipat dua, kini mendekati tingkat membahayakan bagi banyak spesies.

\section{Timah}

Logam berwarna kelabu keperakan yang amat beracun dalam setiap bentuknya ini merupakan ancaman yang amat berbahya bagi anak di bawah usia 6 tahun, yang biasanya mereka telan dalam bentuk serpihan cat pada dinding rumah. Logam berat ini merusak kecerdasan, menghambat pertumbuhan, mengurangi kemampuan untuk mendengardan memahami bahasa, dan menghilangkan kosentrasi. Bahkan pajanan dengan dengan tingkat yang amat rendah sekalipun tampaknya selalu diasosiasikan dengan rendahnya kecerdasan. Karena sumber utama timah adalah asap kendaraan berbahan bakar bensin yang mengandung timah, maka polutan ini dapat ditemui dimana ada mobil, truk, dan bus. Bahkan di Negara-negara yang telah berhasil menghapuskan penggunaan bensin yang mengandung timah, debu di udara tetap tercemar karena penggunaan bahan bakar ini selama puluhan tahun.

Di samping timah,banyak sekali zat beracun lain menambah beban kandungan polutan di daerah perkotaan. Zat-zat ini mulai dari asbes dan loagm berat (seperti cadmium, arsenic, mangan, nikel dan zink) sampai bermacam-macam senyawa organic (seperti benzene dan hidrokarbon lain dan aldehida).

\section{Program Pengendalian Polusi}

Penggunaan kendaraan bermotor menyebabkan lebih banyak polusi udara daripada kegiatan lain apapun, menimbulkan hamper separo oksida nitrogen yang diakibatkan ulah manusia, dua pertiga karbon monoksida, dan separo hidrokarbon di kotakota industri, di samping hamper seluruh timah di udara di Negara-negara berkembang. Di sebagian besar Negara berkembang, sumber pembangkit tenaga pemanas menimbulkan sampai dua pertiga emisi sulfur dioksida dan antara sepertiga sampai setengah emisi total polutan udara yang lain. Jadi, dua prioritas utama bagi program pengendalian pencemaran adalah kendaraan bermotor dan sumber pembangkit tenaga, walaupun di beberapa Negara berkembang pusat perhatian utama adalah pengendalian pencemaran yang timbul 
dari penggunaan batubara murah yang banyak digunakan untuk memasak dan alat pemanas rumah tangga.

Kecuali kota-kota yang saran transportasi utamanya masih sepeda dan jalan kaki, hamper tidak mungkin memerangi pencemaran udara tanpa "menyerang" pipa knalpot sepeda motor/skuter, mobil, truk dan bus. Bahkan di kota-kota yang masih "didominasi" oleh sepeda, jumlah mobil kini semakin meningkat. Lebih dari 500 juta mobil dan kendaraan umum umum kini memadati jalan-jalan dunia, 10 kali lebih lipat jumlah pada 1950 dan menurut proyeksi terbaru, jumlah kendaraan di dunia akan berlipat dua dalam 40 tahun mendatang, sampai kira-kira satu miliar. Kebanyakan pertambahan ini akan terjadi di Negara-negara berkembang, yang permintaan mobilnya di perkirakan meningkat $200 \% \mathrm{di}$ akhir abad ini; dengan demikian sangat memperburuk masalah pencemaran saat ini, terutama di perkotaan.

Di daerah-daerah yang masih menggunakan bensin bermuatan timah, salah satu strategi pengendalian pencemaran yang paling efektif adalah sama sekali melarang penggunaan zat aditif tersebut, atau menurunkan secara tajam tingkat yang diperbolehkan dalam bensin.beberapa kota dan negara amat menghendaki adanya bahan bakar alternatif yang membakar lebih bersih dari pada bensin dan minyakl diesel berbahan dasar petroleum yang konvensional. Pilihan-pilihan antara lain berupa campuran "berwawasan lingkungan". Hasil formulasi ulang yang menurunkan daya penguapnya dan demikian menurunkan pula ada emisi senyawa organic yang mudah menguap dan mudah menurunkan konsentrasi benzene dan komponen beracun lain.

Pilihan lain adalah "mengoksigenasi" bahan bakar tersebut dengan menambahkan alkohol. "Gasohol" (bensin dan alkohol) semacam itu terbakar lebih sempurna dan dengan demikian menurunkan emisi karbon dioksida.bahan bakar diesel dengan tingkat sulfur yang diturunkan mengeluarkan sulfur dioksida dan polutan lain yang lebih sedikit.

Pilihan lain yang lebih baik adalah alternatif non-petroleum seperti methanol, etanol, gas alam yang di manfaatkan atau gas petroleum cair, hydrogen atau batrei listrik karma bahan-bahan tersebut sama sekali menghapus pencemaran oleh pipa knalpot. 


\section{Polusi udara karena kendaraan bermotor}

Perintah pelaksanaan ZEV baru merupakan satu komponen dari berbagai aturan standar pipa knalpot yang lebih ketat dan rumit yang diisyaratkan dalam usahanya untuk secara tajam menurunkan pencemaran dari mobil, truk, dan bus. Peraturan Negara bagian ini juga mensyaratkan penjualan kendaran ber emisi ultra-rendah (“Ultra-low emiting vehicles/ULEV') dan kendaraan transisi beremisi rendah ("transitional-low emiting vehicles/TLEV') yang semuanya di perhitungkan untuk memasukan tidak hanya sejauh ini mobil-mobil yang lebih bersih, tetapi juga bahan bakar yang lebih bersih ke pasaran.

Lebih jauh, karna alasan praktis, mobil bertenaga baterai sekali dipasarkan akan mencapai dan mempertahankan pasan kendaraan ringan yang semakin besar memberlakukan pula ZEV/LEV. Jika diasumsikan lebih jauh bahwa tiap mobil dikemudikan sejauh rata-rata disaat ini,yaitu $48 \mathrm{Km}$ tiap hari,menggunakan 0.5 kilowatt, jam per 1,6 Km (konsumsi bertenaga batrei TEVAN dari Chrysler, yang merupakan mobil listrik paling boros sampai sekarang), maka tiap mobil akan mengkonsumsi 15 kilowatt sehari semalam, dengan waktu isi ulang ("recharge") delapan jam.konsumsi keseluruhan dari semua kendaran ini berjumlah kurang lebih 4 juta kilowatt atau $1 \%$ kenaikan pada permintaan puncak.untuk mengubah semua jenis kendaraan itu menjadi kendaraan bertenaga batrei diperlukan peningkatan kebutuhan listrik sekitar 25\% tetapi juga penurunan emisi karbon dioksida dalam jumlah yang sama, asalkan konsumsi listrik sama dengan saat ini.

Dengan demikian, mobil bertenaga listrik akan membawa dua berita baik: pencemaran seperti asap kabut dan karbon monoksida akan sangat terkurangi karena penghapusan knalpot, pencemaran pemanasan global seperti karbon dioksida akan terkendali dengan digantinya mesin berpembakaran di dalam (internal combustion engine) oleh pembangkit tenaga sentral yang lebih efisien dari TEVAN, maka keuntungan akan lebih besar lagi.

\section{Cari lain Menangani Polusi Akibat Kendaraan Bermotor.}

Bagi banyak daerah perkotaan, usaha melengkapi kendaraan, seperti angkutan kota, skuter, dan mobil dengan perangkat kendali yang canggih, walaupun efektif, tidak mengurangi pencemaran udara dengan cukup cepat dan menyeluru. Kota-kota ini telah 
menjalankan program, mulai dari pemberlakuan hari tanpa berkendaraan, sampai pelarangan parkir di kota yang kesemuanya dikenal dengan istilah upaya pengendalian transportasi (transportation control measures. Banyak TCM dipusatkan pada pengurangan kepadatan lalu lintas, dengan menggunakan sistem yang berkisar dari metode fisik, seperti lampu lalu lintas yang terkoordinasi, jalan satu arah dan mobil patungan atau jalur bus yang terpisah, sampai metode penggunaan insentif ekonomi, misalnya "tarif jalur padat" yang mengharuskan pengemudi membayar jika jalan raya di saat lalu lintas padat.

\section{Larangan Masuk}

Melarang kendaraan pribadi memasuki jalan-jalan pusat keramaian kota dari pukul 10 pagi sampai 7 malam pada hari-hari kerja. Bus dan taksi diperbolehkan hanya pada beberapa jalan tertentu. Larangan ini mengatasi kepadatan lalu lintas dan pencemaran udara yang disebabkan oleh kendaraan orang yang memadati pusat kota setiap hari kerja.

\section{Larangan Parkir}

Larangan parkir membatasi jumlah kendaraan yang boleh parkir di suatu daerah, tapi tidak dipengaruhi apapun pada jumlah mobil yang boleh lewat. Salah satu cara untuk mengatasi masalah yang diakibatkan oleh berlimpahnya kendaraan adalah sama sekali melarang semua kendaraan memasuki pusat-pusat kota. "Zona bebas mobil" sebagai suatu cara untuk mengurangi pencemaran udara, menggalakkan pariwisata, dan meningkatkan kulitas kehidupan. Zona pembatasan mobil biasanya hanya berlaku pada daerah pariwisata atau pertokoan kecil dan hanya berdampak kecil pada pola transportasi kota secara keseluruhan.

\section{3. "Sel" Lalu Lintas}

Membagi pusat kotanya menjadi lima sektor berbentuk "pastel" sebagai suatu cara untuk membatasi lalu lintas yang lewat dan menggalakkan transportasi umum. Kendaraan darurat, angkutan lokal massal, sepeda dan moped dapat melintasi dari satu zona ke zona lain, tapi mobil tadak dapat. Berkurangnya kepadatan di pusat kota telah menimbulkan layanan transit yang lebih baik dan tingkat kecelakaan yang lebih rendah. Pendekatan yang disebut "Sel lalu lintas"ini yang berasal dari Bremen, Jerman. 


\section{Hari Tanpa Pengemudi}

Dalam langkah ini mencanangkan "perang" terhadap pencemaran dengan cara membatasi jumlah mobil di jalan. Dalam peraturan ini, mobil berplat nomor ganjil dilarang berjalan disuatu hari, sedang mobil berplat nomor genap dilarang hari berikutnya.

\section{Bersepeda}

Berbagai bentuk transportasi yang paling lazim di dunia, bersepeda kini mulai "naik daun" sejalan dengan usaha pemerintah beberapa Negara untuk menggalakkan bersepeda melalui program khusus. Jumlah sepeda di planet ini lebih dari 800 juta, hampir dua kali kendaraan umum, tetapi untuk lebih menggalakkan bersepeda Negara setempat mengembangkan jaringan jalan untuk sepeda, masing-masing dengan hak guna jalan yang terpisah dari jumlah mobil. Tempat parkir yang terpisah, persewaan sepeda dengan uang jaminan yang akan dikembalikan, bahkan garasi khusus sepeda, semuanya diusahakan untuk lebih menggalakkan kegiatan bersepeda. Program semacam itu mempunyai dampak besar terhadap cara orang melihat pilihan mereka memiliki untuk sarana transportasi.

\section{Jam Kerja Lentur}

Saat ini banyak kota mencari jalan untuk menghambat pencemaran udara dengan cara memulai jam kerja atau sekolah satu atau dua lebih awal, atau dengan mengakhirinya lebih awal, dan dengan demikian mengurangi kepadata lalu lintas. Kota-kota lain mengusulkan empat hari jam kerja seminggu sebagai cara lain mengurangi kemacetan lalu lintas.

\section{Pembangkit Tenaga Listrik}

Pusat pembangkit tenaga listrik sudah lama dianggap mahal dan sulit di kendalikan oleh banyak Negara, dan kini semakin sering menjadi sasaran bagi teknologi dan praktek-praktek baru, dan dengan alasan yang baik pula : karena disamping kendaraan bermotor, fasilitas ini merupakan sumber terbesar pecemaran udara. Pembangkit tenaga listrik mengeluarkan hampir dua pertiga dari seluruh sulfur dioksida, 
dan hampir sepertiganya dari seluruh oksida nitrogen. Walaupun ada data tentang polutanpolutan lain, namun data itu hampir pasti juga berlaku bagi emisi-emisi lain, terutama partikulat dan logam berat dan secara tidak langsung ozon. Penggunaan listrik meungkin sekali akan terus meningkat secara global, karena permintaan akan listrik meningkat sebanyak 10 persen setiap tahun di beberapa Negara, dan itu berarti suatu penggandaan konsumsi setiap kira-kira tujuh tahun.

\section{Pencegahan Pencemaran}

Pakar ekonomi AS, Robert Hamrin, menyebutkan pencegahan pencemaran sebagai "daya paling penting untuk membuat industri mempertimbangkan kembali dan mengubah proses produksi dan manajemen". Sejak pertengahan 1990 hampir dari dua perusahaan mangatakan mereka telah mencanangkan tindakan-tindakan lingkungan yang penting.perusahaan 3M, misalnya, telah menhemat 530 juta dollar AS sejak 1975, ketika perusahaan itu mulai menerpakan program "3P" (Pollution Prevention Pays) yang artinya "mencegah pencemaran itu menguntungkan". Perusahaan bahan kimia itu telah mencegah lebih dari 575.000 ton pencemaran. Dari kasus suatu perusahaan semboyan "pencegahan pencemaran menjadi gaya hidup", sangat meningkatkan keuntungan dan daya perusahaan tersebut.

Di salah satu pabrik farmasi 3M di California, penggantian pelapis tablet berbahan dasar pelarut menjadi berbahan dasar air telah menghemat 120.000 dollar AS setahun, dan sekaligus juga mengurangi pencemaran udara. Dipabrik Du Pont di Beaumont, Texas, misalnya, suatu program pencegahan pencemaran mengurangi emisi udara kurang lebih 27 juta kilo setahun, sekaligus menghemat hampir 1 juta dollar AS biaya produksi tahunan. Kira-kira 1.200 perusahaan secara sukarela menyatakan akan mengurangi 160 juta kilo dari 17 jenis zat kimia terpenting.

\section{KESIMPULAN}

1. Pembangunan transportasi diarahkan pada terwujudnya sistem transportasi nasional yang andal, berkemampuan tinggi, diselenggarakan secara terpadu, meningkatkan kebijakan yang berkaitan dengan peningkatan kemampuan Sumber Daya Manusia. 
2. Diwilayah perkotaan dikembangkan transportasi massal yang tertib, lancar dan aman dan nyaman dan efisien yang memberikan kualitas lingkungan hidup, pembangunan transportasi darat diarahkan pada pengembangan secara terpadu antara transportasi jalan raya, kereta api, sungai, danau dan penyebrangan melalui pembangunan sarana, prasarana dengan meningkatkan manajemen dan pelayanan serta pembinaan pemakai jalan dan kejelasan informasi agar dapat memacu pembangunan di semua sektor.

3. Dalam rangka tujuan-tujuan dan strategi-strategi yang ditetapkan, telah diidentifikasikan 9 (sembilan) kebijaksanaan antara lain : 1) Kerangka hukum dan pengaturan ; 2) Pengembangan institusi dan koordinasi; 3) Pengintegrasian Perencanaan Dan Kebijaksanaan Sektor Angkutan Perkotaan; 4) Pembangunan Infrastuktur Angkutan Jalan Perkotaan; 5) Meningkatkan Pengaturan Lalu Lintas Di Daerah-Daerah Perkotaan; 6) Meningkatkan Pelayanan Angkutan Umum Perkotaan; 7) Pengembangan Sistem Angkutan Cepat Massal; 8) Meningkatkan Keselamatan Lalu Lintas Di Jalan; 9) Pengendalian Lingkungan Perkotaan

4. Bahan pencemar di udara adalah : 1. Karbon monoksida; 2. Nitrogen Oksida; 3. Sulfur Dioksida; 4. Benda Partikulat; 5. Hidro karbon; 6. Laju Pelaksanaan Untuk Kendaraan Beremisi Nol atau Mendekati Nol (TLEV, LEV, ULEV dan ZEV); 7. Ozon atau Kabut Fotokimiawi; 8. Timah

5. Program pengendalian polusi di kota-kota besar dapat dilakukan dengan kebijakan penggunaan smart card (pengurangan konsumsi bensin/solar), dengan menggalakkan bersepeda dan jalan kaki, atau dengan "mengoksigenasi" bahan bakar dengan menambahkan alkohol, pilihan lainnya adalah alternatif nonpetroleum seperti methanol, etanol, gas alam yang di manfaatkan atau gas petroleum cair, hydrogen atau batrei listrik karma bahan-bahan tersebut sama sekali menghapus pencemaran oleh pipa knalpot.

6. Program lain dengan upaya pengendalian transportasi (transportation control measures) dengan cara pengaturan lampu lalu lintas yang terkoordinasi, jalan satu arah dan mobil patungan atau jalur bus yang terpisah, sampai metode penggunaan insentif ekonomi, misalnya "tarif jalur padat" yang mengharuskan pengemudi membayar jika jalan raya di saat lalu lintas padat, membuat larangan 
masuk, larangan parkir, sel lalu lintas, hari tanpa pengemudi, jam kerja lembur, pembangkit tenaga listrik atau surya.

\section{DAFTAR PUSTAKA}

Achmad, Rukaesih, 2004, Kimia Lingkungan, Penerbit ANDI, Jakarta.

Bianpoen, 2004, Menata Ruang Kota, Untuk Apa/Siapa ?, jurnal lingkungan, Program Studi Teknik Lingkungan, Program Pasca Sarjana UI, Jakarta.

Blodgett, John, 1989, Health Benefits of Air Pollution Control; A Disscussion. Washington DC, Conggressional Research Service, Library of Congress.

Lu, Frank C, 1995, Toksologi Dasar (Terjemahan , Adi Nugroho), UI Press, Jakarta.

Moore, Curtis, 2008, Mutu Udara Kota, makalah hijau, dibrowsing tanggal 28 Mei 2008 pukul 10.00 wib, hhtp://www.usembassyjakarta.org.

Peraturan Pemerintah No 82 tahun 2001 tentang Pengelolaan Kualitas Air dan Pengendalian Pencemaran Air, dibrowsing tanggal 28 Mei 2008 pukul 10.00 wib, hhtp://www.menlh.go.id 